Tropical Journal of Pharmaceutical Research September 2018; 17 (9): 1693-1699

ISSN: 1596-5996 (print); 1596-9827 (electronic)

(1) Pharmacotherapy Group, Faculty of Pharmacy, University of Benin, Benin City, 300001 Nigeria.

\title{
Effect of polymer ratio on the quality of a co-processed excipient of prosopis gum and crab shell chitosan
}

\author{
Emmanuel O Olorunsola*, Susan G Usungurua \\ Department of Pharmaceutics and Pharmaceutical Technology, University of Uyo, Uyo, Nigeria
}

*For correspondence: Email: olorunsolaeo@yahoo.com; Tel: +2348035067306

Sent for review:

Revised accepted: 11 May 2018

\begin{abstract}
Purpose: To assess the effect of polymer ratio on the quality of a novel co-processed excipient of prosopis gum and crab shell chitosan.

Methods: The physicochemical properties (DSC thermogram, powder flow properties, porosity and swelling index as well as $\mathrm{pH}$, viscosity and adhesive strength of $2 \% \mathrm{WV}$ dispersions) of prosopis gum, chitosan and the three grades of co-processed excipient of prosopis gum and crab shell chitosan (Prosochit $\Theta 201$, Prosochit $\Theta 101$ and Prosochit $\Theta 102$ ) were determined.

Results: The three grades of the co-processed excipient of prosopis gum and crab shell chitosan (Prosochit(B) were characterized by one endothermic transition each with peaks at $180^{\circ} \mathrm{C}, 179^{\circ} \mathrm{C}$ and $178{ }^{\circ} \mathrm{C}$ for Prosochit $\Theta 201$, Prosochit $\Theta 101$ and Prosochit $\Theta 102$ respectively. Flow properties increased with increase in proportion of chitosan. The porosity of the three grades of the new excipient was not significantly different from that of prosopis gum. Swelling indices of prosopis gum, chitosan, Prosochit ${ }$ 201, Prosochit $(3101$ and Prosochit $\Theta 102$ were $1135.53 \%, 14.00 \%, 726.33 \%, 677.33 \%$ and $514.00 \%$ respectively. The viscosity also decreased with increase in the proportion of chitosan. The new excipient had higher adhesive strength compared to the individual constituents (prosopis gum and crab shell chitosan).

Conclusion: Prosochit $\Theta$ is superior to its individual constituents as a tableting excipient but its suitability for liquid formulation is reduced by increase in the proportion of chitosan.
\end{abstract}

Keywords: Polymer ratio, Crab shell chitosan, Prosopis gum, Prosochit ${ }^{\circledR}$

\begin{abstract}
This is an Open Access article that uses a funding model which does not charge readers or their institutions for access and distributed under the terms of the Creative Commons Attribution License (http://creativecommons.org/licenses/by/4.0) and the Budapest Open Access Initiative (http://www.budapestopenaccessinitiative.org/read), which permit unrestricted use, distribution, and reproduction in any medium, provided the original work is properly credited.
\end{abstract}

Tropical Journal of Pharmaceutical Research is indexed by Science Citation Index (SciSearch), Scopus, International Pharmaceutical Abstract, Chemical Abstracts, Embase, Index Copernicus, EBSCO, African Index Medicus, JournalSeek, Journal Citation Reports/Science Edition, Directory of Open Access Journals (DOAJ), African Journal Online, Bioline International, Open-J-Gate and Pharmacy Abstracts

\section{INTRODUCTION}

Pharmaceutical polymers are polymers that are used for the purpose of drug delivery. They serve different purposes in the manufacture as well as in the performance of pharmaceutical preparations $[1,2]$. They are used as excipients in solid, semi-solid and liquid dosage forms [3-5]. Chemically, pharmaceutical polymers can be classified into: starch-based polymers, cellulosebased polymers, hydrocolloids, chitosan and synthetic polymers [6-10].The variation in chemical composition of polymers is responsible for their different physical, thermal, mechanical and functional properties [11].

If a polymer cannot address the needs of a particular application, its properties can be 
modified. Alternatively, two or more polymers can be combined either by blending or by chemical reaction [12]. Polymer blends are simply made by physical mixing or co-processing of two or more polymers in molten or solution state [13]. Co-processing leads to the formation of excipient granulates with superior properties compared with mere physical mixtures of individual components. It is another way of producing new excipients without undergoing the rigorous safety testing of a completely new chemical [14]. The excipients chosen for co-processing should be such that they complement each other to mask the undesirable properties of individual excipients and at the same time, retain or improve the desired properties [15]. An excipient of reasonable price can be combined with optimal amount of a functional material in order to obtain superior functionality than the simple mixture of components [14].

Prosochit $^{\circledR}$, NG Patent 2016/00355, is a novel co-processed excipient of prosopis gum (PRG) and crab shell chitosan (CTS) [16]. It is of three grades and coded as Prosochit ${ }^{\circledR} 201$ (PC201), Prosochit $^{\Theta} 101$ (PC101) and Prosochit ${ }^{\Theta} 102$ (PC102). The three grades contain the two polymers (prosopis gum and crab shell chitosan) at different proportions of $2: 1,1: 1$ and $1: 2$ respectively. The prosopis gum was obtained from the seeds of Prosopis africana while the chitosan was obtained from shell wastes of Callinectes gladiator. The Fourier transform infrared spectra of prosopis gum, crab shell chitosan and Prosochit $^{\Theta} 101$ in the work of Olorunsola [16] showed that prosopis gum and chitosan are compatible.

Prosopis africana is widely distributed in the tropical region [17]. The gum is made up of highly branched polysaccharides with chain structure which is formed when monosaccharides condense with the elimination of water molecules. It is a natural polysaccharide consisting mainly of glucose, fructose, galactose and xylose as the monosaccharide units [18]. Its high bioadhesive strength is commensurate with those of Carbopol 974-P and sodium carboxylmethylcellulose [19].

Like other crustaceans, shells of members of the genus Callinectes are good source of chitosan [20]. The swimming crab, Callinectes gladiator Benedict is a decapod crustacean which is abundantly available in the coastal towns of West Africa [21]. Purified grades of chitosan are useful for biomedical and pharmaceutical applications [22]. Earlier work has shown that crab shell chitosan incorporated as permeation enhancer at concentrations of $1-5 \%$ had a positive influence on the disintegration and dissolution of ciprofloxacin tablet as well as on permeation of the drug [20].

Prosopis gum and chitosan are two polymers of different origins and different properties. The three grades of Prosochit $^{\Theta}$ contain the two polymers in different proportions; and are likely to exhibit different properties. The aim of this study is to assess the effect of polymer ratio on the quality of Prosochit ${ }^{\Theta}$, a coprocessed excipient of the two polymers. A good knowledge of the behaviour of the different grades will help in identifying the appropriate use.

\section{EXPERIMENTAL}

\section{Materials}

The materials used were: Prosochit $^{\circledR}$ 201, Prosochit $^{\Theta} 101$, Prosochit ${ }^{\circledR}$ 102, prosopis gum extracted from seeds of Prosopis africana; and crab shell chitosan (degree of deacetylation of $62.7 \%$ ) obtained from shells of Callinectes gladiator as described in NG Patent 2016/00355 [16].

\section{Differential scanning calorimetry (DSC)}

DSC analysis was carried out on individual components (prosopis gum and crab shell chitosan) and on the three grades of Prosochit ${ }^{\circledR}$. Analysis of each sample, placed in an Al $40 \mu \mathrm{L}$ crucible was carried out using a STAR $^{\mathrm{e}} \mathrm{SW}$ 12.10 DSC machine (Mettler-Toledo, GmbH Germany). The scanning was carried out over a temperature range of $50-350{ }^{\circ} \mathrm{C}$.

\section{Density measurement}

A $10 \mathrm{~g}$ sample of excipient was placed in a $25 \mathrm{ml}$ measuring cylinder and the bulk volume was taken. The system was tapped 500 times after which the volume was retaken. The bulk density (BD) and tapped density (TD) were calculated as the ratio of mass to the corresponding volume.

The true density $\left(D_{t}\right)$ of the excipients (prosopis gum, crab shell chitosan and the three grades of Prosochit ${ }^{\Theta}$ ) were determined by the specific gravity bottle method. A clean $25 \mathrm{ml}$ specific gravity bottle was filled with xylene and the weight of the bottle with xylene was determined. Some of the xylene was poured out and $1 \mathrm{~g}$ of sample was transferred into the bottle. More xylene was added until the bottle was filled. The excess fluid was wiped off and the weight of the bottle and its content was taken. The true density was calculated using Eq 1. 
$D t=(w / a+w-b) \times S G$

where $w$ is the weight of excipient, $a$ is weight of bottle + xylene; $b$ is weight of bottle + xylene + excipient and $S G$ is the specific gravity of xylene.

\section{Determination of flow properties}

For each of the excipients (prosopis gum, crab shell chitosan and the three grades of Prosochit $\left.{ }^{\circledR}\right), 20 \mathrm{~g}$ of sample was poured inside a funnel of orifice diameter $0.75 \mathrm{~cm}$ clamped at height $10 \mathrm{~cm}$ from the table surface. The sample was allowed to flow freely and the angle of repose, $\Theta$, was calculated using Eq 2 .

$\Theta=\operatorname{Tan}^{-1}(2 h / D)$

where $h=$ height of heap and $D$ is the diameter.

The Carr's index $(\mathrm{Cl})$ and Hausner's ratio (HR) were calculated using the two equations below [23]:

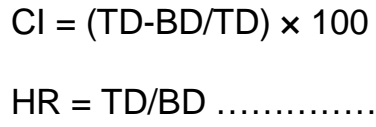

$\mathrm{HR}=\mathrm{TD} / \mathrm{BD}$

\section{Determination of powder porosity}

The powder porosity $\Phi$ was determined using Eq 5.

$\varnothing=1-B D / D$

where $B D=$ bulk density and $D_{t}=$ true density of excipient.

\section{Determination of swelling index (SI)}

A $2 \mathrm{~g}$ sample of excipient was weighed and transferred into a $50 \mathrm{ml}$ measuring cylinder containing distilled water. The initial volume of the excipient inside the measuring cylinder was taken. The system was left for $24 \mathrm{~h}$ after which the swollen volume of the excipient was taken.

$\mathrm{SI}=(\mathrm{Vf}-\mathrm{Vo} / \mathrm{Vo}) \times 100$

where $V_{f}$ is the swollen volume and $V_{o}$ is the initial volume of the excipient.

\section{pH measurement}

The $\mathrm{pH}$ of $2 \% \mathrm{w} / \mathrm{v}$ dispersion of each excipient (prosopis gum, crab shell chitosan and the three grades of Prosochit ${ }^{\Theta}$ ) was determined $24 \mathrm{~h}$ after preparation using a $\mathrm{pH}$ meter.

\section{Determination of apparent viscosity of the mucilage}

The viscosity of a $2 \% \mathrm{w} / \mathrm{v}$ dispersion of each excipient was measured $6 \mathrm{~h}$ after preparation using a DV1 prime viscometer (Brookfield Engineering, U.S.A.). About $70 \mathrm{ml}$ of the gum dispersion was placed in the cup of the viscometer, spindle 1 was inserted and the reading was taken at room temperature and 60 rpm.

\section{Determination of adhesive strength}

Dispersions $(100 \mathrm{ml})$ of different excipients at concentration of $2.0 \% \mathrm{w} / \mathrm{v}$ were prepared, stirred and left for $6 \mathrm{~h}$ for hydration and dissolution. A Searls tensiometer (Philip Harris P23660/9, England) was used for determination the surface tension of each of the dispersions. The circular plate was submerged below the surface of the dispersion and then gradually raised upward. The equipment was zeroed when the plate was just at the surface of the dispersion. The plate was subsequently raised until it just detached from the surface of the liquid. The reading was taken from the scale and converted to $\mathrm{kg}(10 \mathrm{~mm}$ being equivalent to $10^{-3} \mathrm{~kg}$ as specified on the instrument). The adhesive strength of each dispersion was calculated using the modified form of the equation of Sharma et al [24].

AS $=m g / \pi r^{2}$

where AS is the adhesive strength, $m$ is the mass causing detachment, $g$ is acceleration due to gravity, $r$ is the radius of the circular plate.

\section{Statistical analysis}

Data were expressed as mean \pm standard error of mean (SEM). Statistical analysis was done using GraphPad Instat-3 package. Significance of difference was set at $p$-values less than 0.05 .

\section{RESULTS}

\section{DSC thermograms}

The DSC thermograms of prosopis gum, crab shell chitosan and the three grades of Prosochit ${ }^{\circledR}$ are shown in Figure 1. The DSC thermogram of prosopis gum was characterized by an exothermic peak at $310{ }^{\circ} \mathrm{C}$ while that of chitosan was characterized by two endothermic peaks at 129 and $179{ }^{\circ} \mathrm{C}$. The three grades of Prosochit ${ }^{\circledR}$ were characterized by one endothermic transition each. The peaks were at positions $180^{\circ} \mathrm{C}, 179$ ${ }^{\circ} \mathrm{C}$ and $178{ }^{\circ} \mathrm{C}$ for PC201, PC101 and PC102 respectively. 


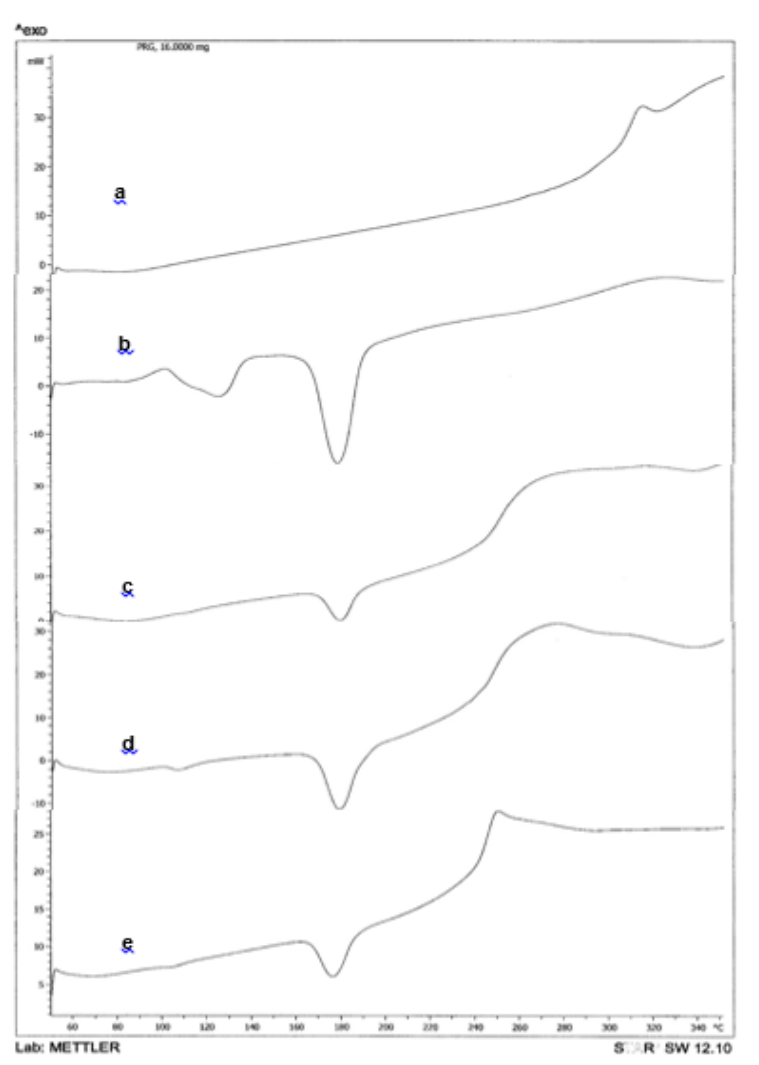

Figure 1: DSC thermograms of (a) prosopis gum (b) crab shell chitosan (c) Prosochit ${ }^{\circledR} 201$ (d) Prosochit ${ }^{\circledR}$ 101 (e) Prosochit ${ }^{\circledR} 102$

\section{Density}

The bulk, tapped and true densities of prosopis gum, crab shell chitosan and the three grades of Prosochit $^{\circledR}$ are shown in Table 1. The bulk densities of prosopis gum and chitosan were not significantly different. Those of the three grades of Prosochit ${ }^{\circledR}$ were significantly lower. The same observations were recorded for the tapped

Table 1: Density of the excipients densities. There was a significant difference between the true density of prosopis gum and that of chitosan.

\section{Flow properties}

The flow properties of the excipients are shown in Table 2. The values of angle of repose of prosopis gum and chitosan were not significantly different from those of the three grades of Prosochit ${ }^{\circledR}$. There was no significant difference in the Hausner's ratio of the different excipients, neither was there any significant difference in the Carr's index.

\section{Porosity}

The porosity values of the different excipients are shown in Figure 2. The porosity values of the three grades of Prosochit ${ }^{\circledR}$ were not significantly different from that of prosopis gum but were significantly different from that of chitosan.

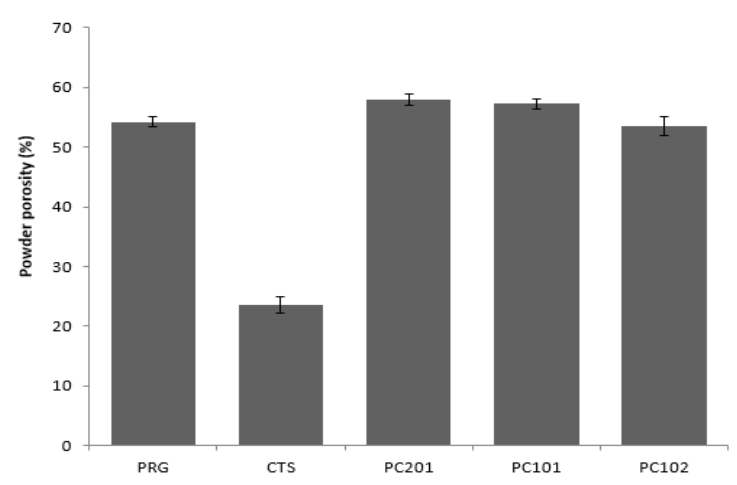

Figure 2: A plot of porosity of the excipients $(P R G=$ prosopis gum, CTS $=$ crab shell chitosan, PC201= Prosochit $^{\circledR}$ 201, PC101 = Prosochit $^{\circledR}$ 101, PC102= Prosochit $^{\circledR}$ 102)

\begin{tabular}{lccc}
\hline Polymer & Bulk density $(\mathbf{g} / \mathbf{m l})$ & Tapped density $(\mathbf{g} / \mathbf{m l})$ & True density $(\mathbf{g} / \mathbf{m l})$ \\
\hline Prosopis gum & $0.71 \pm 0.00$ & $0.84 \pm 0.01$ & $1.55 \pm 0.00$ \\
Crab shell chitosan & $0.81 \pm 0.01$ & $0.94 \pm 0.01$ & $1.06 \pm 0.00$ \\
Prosochit $^{(B)} 201$ & $0.55 \pm 0.00$ & $0.66 \pm 0.01$ & $1.31 \pm 0.00$ \\
Prosochit $^{(B)} 101$ & $0.53 \pm 0.00$ & $0.64 \pm 0.01$ & $1.24 \pm 0.00$ \\
Prosochit $^{(B)} 102$ & $0.53 \pm 0.01$ & $0.63 \pm 0.01$ & $1.14 \pm 0.00$ \\
\hline
\end{tabular}

Data are mean \pm SEM $(n=3)$

Table 2: Flow properties of the excipients

\begin{tabular}{lccc}
\hline Polymer & Angle of repose $\left(^{\circ}\right)$ & Hausner's ratio & Carr's index (\%) \\
\hline Prosopis gum & $31.19 \pm 0.59$ & $1.19 \pm 0.01$ & $15.77 \pm 1.31$ \\
Crab shell chitosan & $27.34 \pm 1.12$ & $1.15 \pm 0.02$ & $13.50 \pm 1.16$ \\
Prosochit $^{(B)} 201$ & $28.69 \pm 0.54$ & $1.19 \pm 0.02$ & $16.22 \pm 0.84$ \\
Prosochit $^{(B)} 101$ & $28.25 \pm 0.10$ & $1.19 \pm 0.02$ & $16.16 \pm 1.59$ \\
Prosochit $^{(B)} 102$ & $26.29 \pm 0.48$ & $1.17 \pm 0.01$ & $14.78 \pm 1.17$ \\
\hline
\end{tabular}


Table 3: Physicochemical properties of $2 \% \mathrm{w} / \mathrm{v}$ dispersions of the excipients

\begin{tabular}{lccc}
\hline Polymer & pH & $\begin{array}{c}\text { Viscosity } \\
\text { (mPas) }\end{array}$ & $\begin{array}{c}\text { Adhesive strength } \\
\left(\mathbf{N m}^{-2}\right)\end{array}$ \\
\hline Prosopis gum & $8.31 \pm 0.01$ & $7.18 \pm 0.00$ & $13.80 \pm 1.48$ \\
Crab shell chitosan & $10.66 \pm 0.04$ & $2.88 \pm 0.04$ & $13.26 \pm 0.24$ \\
Prosochit $^{(8)}$ 201 & $10.13 \pm 0.02$ & $4.47 \pm 0.04$ & $15.12 \pm 0.80$ \\
Prosochit $^{(8)} 101$ & $10.16 \pm 0.00$ & $3.89 \pm 0.04$ & $14.59 \pm 0.96$ \\
Prosochit $^{(B)} 102$ & $10.22 \pm 0.03$ & $3.26 \pm 0.02$ & $14.06 \pm 0.27$ \\
\hline
\end{tabular}

Data are mean \pm SEM $(n=3)$

\section{Swelling index}

The swelling index values of the five excipients are shown in Figure 3. There was a significant difference in the swelling index of the excipients $(p<0.0001)$. The swelling index of Prosochit ${ }^{\circledR}$ decreased with increase in the proportion of chitosan.

\section{Physicochemical properties of dispersions of the excipients}

The $\mathrm{pH}$, viscosity and adhesive strength of $2 \%$ $\mathrm{w} / \mathrm{v}$ dispersion of the excipients are shown in Table 3. The $\mathrm{pH}$ of Prosochit $^{\Theta}$ increased with increase in proportion of chitosan. There was a significant difference in the viscosity of $2 \% \mathrm{w} / \mathrm{v}$ dispersion of the excipients; and the value decreased with increase in the proportion of chitosan. The adhesive strength of Prosochit ${ }^{\circledR}$ varied directly as the proportion of prosopis gum in the new excipient. Prosochit ${ }^{\circledR}$ had higher values of adhesive strength compared to the individual constituents (prosopis gum and crab shell chitosan).

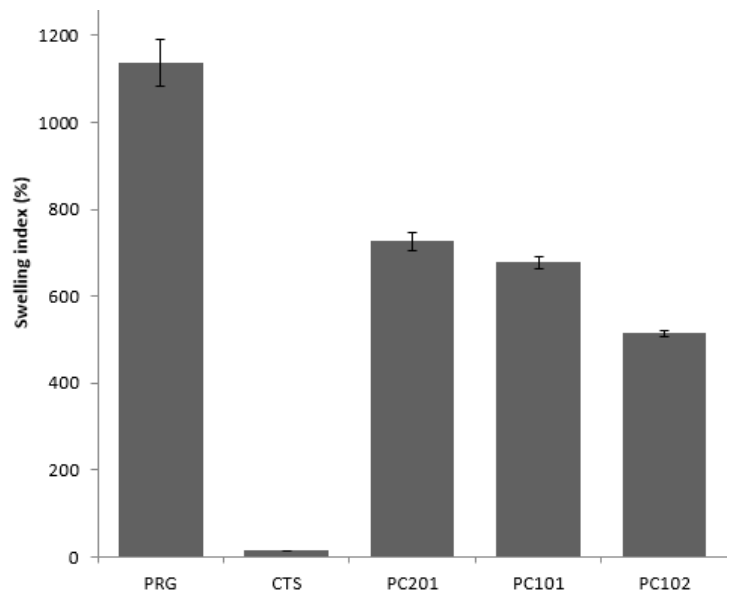

Figure 3: A plot of swelling index of the excipients (PRG $=$ prosopis gum, CTS $=$ crab shell chitosan, PC201 $=$ Prosochit $^{\circledR}$ 201, PC101 $=$ Prosochit $^{\circledR}$ 101, PC102 $=$ Prosochit $^{\circledR}$ 102)

\section{DISCUSSION}

The three grades of the co-processed excipient of prosopis gum and crab shell chitosan were characterized by one endothermic transition each with peaks at $180^{\circ} \mathrm{C}, 179^{\circ} \mathrm{C}$ and $178^{\circ} \mathrm{C}$. Their flow properties increased with increase in proportion of chitosan but deceased viscosity, with porosity similar to that of prosopis gum but swelling indices lower than that of prosopis gum, and higher adhesive strength compared to the individual constituents (prosopis gum and crab shell chitosan).

The exotherm in the thermogram of prosopis gum depicts polymer degradation while the first and second endotherms in the thermogram of crab shell chitosan respectively depict enthalpy relaxation and melting [25]. Hence, crab shell chitosan has melting point of $179^{\circ} \mathrm{C}$. The melting points of the three grades of Prosochit ${ }^{\circledR}$ were close to that of pure chitosan and the values decreased slightly with increase in the proportion of chitosan. Therefore, chitosan has a greater influence on the thermal behaviour of Prosochit ${ }^{\circledR}$.

Co-processing of the two polymers led to production of more loosely packed particles as evident from the bulk and tapped densities. There was a significant difference between the true density of prosopis gum and that of crab shell chitosan; and the true density of Prosochit ${ }^{\circledR}$ decreased with increase in the proportion of chitosan. This implies decrease in compressibility of Prosochit ${ }^{\circledR}$ with increase in the proportion of chitosan as corroborated by the work of Khan and Rhodes [26].

Angle of repose, Hausner's ratio and Carr's index are used as indirect measures of flowability. Based on the angle of repose, the five excipients have good flow in the range of $26-31^{\circ}$. Hausner's ratio between 1.12 and 1.18 (or Carr's index between 11 and 15) indicates good flow while Hausner's ratio between 1.19 and 1.25 (or Carr's index between 16 and 20\%) indicates fair flow [23].

Therefore, the crab shell chitosan and Prosochit ${ }^{\circledR}$ 102 have good flow while the other excipients have fair flow. The better flow of $\operatorname{Prosochit}^{\circledR} 102$ compared to the other two grades of Prosochit ${ }^{\circledR}$ can be linked to the high proportion of chitosan. 
A good flow is a requirement for tableting process.

Co-processing of crab shell chitosan with prosopis gum had no significant effect on the porosity of the latter. Porosity is a measure of the empty space in a material. This is very important to disintegration process in tablets as explained by Gupta and Raud [27]. For disintegrants that work by capillary action, high porosity is advantageous because water uptake is enhanced. For those that work by swelling, high porosity enhances water uptake but reduces the effect of the breaking force because of the void spaces.

Chitosan, as a disintegrant, works by capillary action or wicking [28]. High porosity provides the pathway for fluid penetration for air displacement, bringing about wicking which is the mechanism employed by chitosan. Hence, the high porosity of prosopis gum will enhance the disintegrant effect of chitosan in Prosochit ${ }^{\circledR}$.

The decrease in swelling index of Prosochit ${ }^{\circledR}$ with increase in the proportion of chitosan can be linked to the lower value of the swelling index of chitosan as compared to that of prosopis gum. Swellable polymers are very useful for controlled delivery of drugs [29]. Hence, just like prosopis gum, the three grades of Prosochit ${ }^{\circledR}$ can be investigated for controlled drug delivery. Prosochit $^{\circledR}$ is superior to prosopis gum in that chitosan possesses permeation-enhancing property [30]. The work of Ngwuluka et al [13] showed that combination of two polymers for use as swellable matrix is often superior to the individual ingredient.

The $\mathrm{pH}$ of Prosochit $^{\circledR}$ is intermediate between those of prosopis gum and crab shell chitosan making the new excipient to have wider applicability. Viscosity enhancement is an important phenomenon in the ability of a polymer to function as a suspending, emulsifying or stabilizing agent [10]. Therefore, the decrease in viscosity of dispersion with increase in the proportion of chitosan implies that increase in the proportion of chitosan will lead to decrease in suspending, emulsifying and stabilizing effect of Prosochit $^{\circledR}[31]$.

Compression of tablet and the nature of final product are influenced by the behaviour of the binder or the delivering agent used for its formulation [32]. The adhesive strength of Prosochit ${ }^{\circledR}$ varied directly as the proportion of prosopis gum in this new excipient. The new excipient had higher values of adhesive strength compared to the individual constituents (prosopis gum and crab shell chitosan). This can be attributed to the fact that both prosopis gum and chitosan are bioadhesives [18,30]. Therefore, coprocessing of prosopis gum and chitosan has synergistic effect on adhesive strength. This is an indication of better binding effect and better controlled release property.

\section{CONCLUSION}

Chitosan has a greater influence on the thermal behaviour of Prosochit ${ }^{\circledR}$. The swelling index of Prosochit $^{\circledR}$ is intermediate between those of the gum and the chitosan. The new excipient is superior to both components as it combines the high swelling index of prosopis gum, the inherent permeation-enhancing effect of chitosan and the adhesive properties of the two constituting polymers. There is synergism of properties necessary for tableting; and the new excipient (Prosochit $^{\circledR}$ ) also possesses better indices for use for controlled drug delivery. In terms of liquid formulation, the potential usefulness of this new excipient as suspending, emulsifying and stabilizing agent reduces with increase in the proportion of chitosan.

\section{DECLARATIONS}

\section{Acknowledgement}

The authors are thankful to Messrs Ema E Uduk and Ifiok $\mathrm{O}$ Edem of the Pharmaceutical Technology laboratory of University of Uyo, Uyo, Nigeria for their technical support.

\section{Conflict of Interest}

No conflict of interest associated with this work.

\section{Contribution of Authors}

The authors declare that this work was done by the authors named in this article and all liabilities pertaining to claims relating to the content of this article will be borne by them.

\section{REFERENCES}

1. Esezobo S, Zubair S, Pilpel N. Effect of tapioca obtained from cassava (Manihotutilissima) on the disintegration and dissolution rate of paracetamol tablet. $J$ Pharm Pharmacol 1989; 41(1):7-10.

2. Moreton RC. Excipient functionality. Pharm Technol 2004; 98:99-119.

3. Femi-Oyewo MN, Adedokun MO, Olusoga TO. Evaluation of the suspending properties of Albiziazygia 
gum on sulphadimidine suspension. Trop J Pharm Res 2004; 3(1):279-284.

4. Kumar R, Patil MB, Patil SR, Paschapur MS. Evaluation of Anacardium occidentale gum as gelling agent in aceclofenac gel. Int J Pharm Tech Res 2009; 1(3):695704.

5. Tirpude RN, Puranik PK. Rabeprazole sodium delayedrelease multiparticulates: Effect of enteric coating layers on product performance. J Adv Pharm Tech Res 2011; 2(3):184-191.

6. Ofori-Kwakye K, Asantewaa Y, Kipo SL. Physicochemical and binding properties of cashew tree gum in metronidazole tablet formulation. Int J Pharm PharmSci 2010; 2(4):105-109.

7. Sonia TA, Sharma CP. Chitosan and its derivatives for drug delivery. Adv Pol Sci 2011; 243:23-54.

8. Onyishi IV, Chime SA, Ugwu JC. Evaluation of binder and disintegrant properties of starch derived from Xanthosomasagittifolium in metronidazole tablets. Afr $J$ Biotechnol 2013; 12:3064-3070.

9. Goswami S, Naik S. Natural gum and its pharmaceutical applications. J Scilnnov Res 2014; 3(1):112-121.

10. Barker SA. Suspensions. In: Aulton, Michael E., Taylor, Kevin MG, editors. The Design and Manufacture of Medicine. 5th ed. China: Churchill Livingstone Elsevier; 2018. p. 427-445.

11. Ravve A. Principle of Polymer Chemistry, 3rd ed. London: Spinger - Verlag; 2012

12. Ahuja RK, Dhari J, Goel A, Kumar V, Sharma R. Coprocessing of excipients: $A$ review on excipient development for fast dissolving tablets. Int $\mathrm{J}$ PharmIProff Res 2015; 6(3):1264-1274.

13. Ngwuluka NC, Nep El, Ochekpe NA, Odumosu PO, Olorunfemi PO. Eudagrit 100 and polysaccharide polymer blends as matrices for modified-release drug delivery II: Swelling and release studies. Trop J Pharm Res 2015; 14(12):2163-2170.

14. Russell $R$. Synthetic excipients challenge all natural organics - Offer advantages/ challenges to developers and formulators. Pharm Technol 2004; 27:38-50.

15. Marwaha M, Sandhu D, Marwaha RK. Co-processing of excipient: A review of excipient development for improved tableting performance. Intl J Appl Pharm 2010, 2(3):41-47.

16. Olorunsola EO. Prosochit: A group of multifunctional pharma excipient. NG Patent 2016/00355; 2017.

17. Agboola DA. Prosopis africana (Mimosaceae): Stem, roots and seeds in the economy of the savannah areas of Nigeria. Econ Bot 2004; 58 Suppl 1:34-42.

18. Attama AA, Adikwu MU, Okoli N. Studies in bioadhesive granules 1: granules formulated with Prosopis africana gum. Chem Pharm Bull 2000;48(5):734-737.
19. Adikwu MU, Yoshikwa Y, Kanji T. Bioadhesive delivery of metformin using prosopis gum with antidiabetic potential. Biol Pharm Bull 2003;26(5):662-666.

20. Olorunsola EO, Uwah TO, Olayemi OJ, Etukudo UB. Exvivo evaluation of crab shell chitosan as absorption enhancer in ciprofloxacin tablet formulation. Afr $J$ Biotehnol 2016; 15:1930-1935.

21. Akin-Oriola G, Anetekhai $M$, Olowonirejuaro $K$. Morphometric and meristic studies in two crabs: Cardiosomaarmatum and Callinectespallidus. Turk $\mathrm{J}$ Fish AquaSci 2005; 5:85-89.

22. Burrow $F$, Louime $C$, Abazinge $M$, Onokpise $O$. Extraction and evaluation of chitosan from crab exoskeleton as aseed fungicide and plant growth enhancer. American-Eurasian J Agric Env Sci 2007; 2(2):103-111.

23. Aulton ME. Powder flow. In: Aulton, Michael E., Taylor, Kevin MG, editors. The Design and Manufacture of Medicine.5th ed. China: Churchill Livingstone Elsevier; 2018. p. 189-200.

24. Sharma N, Kulkarni GT, Sharma A. Development of novel Abelmoschusesculentus (Okra) gel for nasal delivery of rizatriptan benzoate. Trop J Pharm Res 2013; 12(2): 149-153.

25. Chung H, Lee E, Lim S. Comparison in glass transition and enthalpy relaxation between native and gelatinized rice starches. CarbohydrPolym 2002; 48: 287-298.

26. Khan KA. Rhodes CT. The production of tablets by direct compression. J Pharm Sci 1973; 8:1-5.

27. Gupta GD, Raud RS. Formulation and evaluation of nimesulide dispersible tablets using natural disintegrants. Ind J Pharm Sci 2000; 62:339-342.

28. Ritthidej GC, Chomto P, Pummangura S, Menasveta $P$. Chitin and chitosan as disintegrants in paracetamol tablets. Drug DevInd Pharm 1994; 20:2109-2134.

29. Sun $X F$, Wang $H H$, Jing $Z X$, Mohanathas $R$. Hemicellulose-based $\mathrm{pH}$-sensitive and biodegradable hydrogel for controlled drug delivery. CarbohydrPolym 2013; 92(2):1357-1366.

30. Yin L, Ding J, He C, Cui L, Tang C, Yin C. Drug permeability and mucoadhesive properties of thiolated chitosan nanoparticles in oral insulin delivery. Biomaterials 2009; 30:5691-5700.

31. Chaudhari SP, Akuskar G, Salvankar SS, Bangar J. Evaluation of suspending and emulsifying properties of Citrullus lanatus seeds. Asian J Pharm Cli Res 2014; 7(5):181-185.

32. Sinka IC, Motazedian F, Cocks ACF, Pitt KG. The effect of processing parameters on pharmaceutical tablet parameters. Powder Technol2009; 189:276-284. 